\title{
The Right to Education in Minority Languages in Bosnia And Herzegovina: The Case of Roma Minority
}

\author{
Stiliano Rushaj \\ Phd Candidate, European University of Tirana \\ rushajstiliano@gmail.com
}

\section{Doi:10.5901/ajis.2015.v4n2p441}

\begin{abstract}
The Roma right to education is guaranteed in the constitution of BiH with the same right to have education in the Romani language as well. Although evidence from research and studies conducted by state and non state institution provides data that firstly Roma enrolement in the educational system is very low and secondly Romani language is almost not learned in any school of the country. This situation fells the domestic provisions of the right of education in the language of different citizens of the country and the international standards that the BiH have ratified and incorporated in its domestic legal provisions. This problem has been a concern for almost 10 years, handled from state institutional mechanisms prespective and non governmental organizations. Policy strategy have been proposed and mechanisms have been deployed in order to foreseen the situation but evidence provides that positive shift toward this issue is very low and with less projection for the future. This policy paper provides a policy solution on short to medium term perspective proposing "Encouraging greater Roma participation in primary, lower secondary and post-compulsory education". In order to deal with policy proposal I argue for this following recomendations: 1).Supporting enrolement of Roma children, creating more facilitative process of enrolment of pupils. 2).Creation of special classes within the school rather special school -3).Budgetary Fund for Roma Education .4) Romani classes goal -. Creating tertiary education curricula in order to have specialists to teach Romai in primary or secondary schools.
\end{abstract}

Keywords: Roma minority, Romani language in education, inclusive policies, Bosnia and Herzegovina

\section{Introduction}

The right to education is provided in the constitution of Bosnia and Herzegovina. This right is extended not only toward the three constituent people of $\mathrm{BiH}$ (bonsiaks, serbs and croats) but also to the "others" (the minority groups). The constitution gives to each constituent people the right of education in the ethnic group language and also this right is expanded toward the minority languages ${ }^{1}$. Looking to the education system, which is divided among the constituent people the right of the minority groups to use their own language in certain degree of the education system is still not applicable. The Roma is one of the minority groups that does not benefit the right to use Romani language in their education. This reppresents a breach in the domestic legal provisions ${ }^{2}$ but also the international convenats ${ }^{3}$.

Insofar the Roma community is one of largest minority group in BiH. The 1991 census accounted 8864 people but estimation of a research in 2007 showed that the community was composed at around $76000 .{ }^{4}$ Although these figures might not be objective the situation of Roma within the country has still doubts. After 20 years from the end of the war, the Constitution of Bosnia and Herzegovina, still does not give full citizens right as Bosniaks, Croats and Serbs. This exclusive policies arouses from political rights (excluding to run political positions such as member of the Presidency of

${ }^{1}$ Institution of Human Rights Ombudsman of Bosnia and Herzegovina, 2013 "Special report on the Status of Roma in Bosnia and Herzegovina" pp.13

${ }^{2}$ Constitution of BiH gurantees the right to education to all citizens of the country (constituent people and "others"). Refer to art. 5 and art.12

3 International Covenant on Economic, Social, and Cultural Rights (ICESCR), the General Coments No. 13 Avaiable at: http://www.refworld.org/docid/4538838c22.html

${ }^{4}$ Action Plan of Bosnia and Herzegovina for Addressing Roma Issues in the Fields of Employment, Housing and

Health Care (2008) pp 6.Available at http://www.romadecade.org/cms/upload/file/9296_file2_action-plan-on-employment-housing-andhealth-care--introduction.pdf $n$ r of pages 18 
$\mathrm{BiH}$ to economic and social rights such as the use of the own language for education).

Having in mind the BiH education system, we can agree to say that education is, of course, one of the public spheres in which ethnic engineering can be a powerful tool of favouritism of ethnic core groups and the exclusion of others. Some of the methods in which inclusiveness or exclusiveness can be implied on the concept of citizenship education system structures and the use of languages in schools can be included as the majors to effect this divisions.

In general, policies related to promotion of Roma rights and inclusive policies are coordinated and monitored at the state level by the Ministry of Human Rights and Refugees (MHRR) while the implementation of such policies is primarily within the responsibility of the relevant line ministries at entity and canton level. Also the Roma Board acts as advisory body to the Council of Ministers ${ }^{5}$. In 2007, the Republika Srpska established the Council of National Minorities as a standing working body of the National Assembly ${ }^{6}$. The Roma are organised at entity level with the Council of Roma in the FBiH which comprises elected representatives of Romani civil society. The Council is the main interlocutor for the authorities regarding Roma-related issues? ${ }^{7}$.

On the other hand at the state level, the Council of Ministers adopted the Action Plan on education, but only in 2004 which was later revised in 2010 and a National Strategy in 2005 which declared the so called "decade for Roma" with goals to be achieved in "...children's rights; education and non - discrimination of Roma and awareness raising about necessity of Roma inclusion in all social processes in BiH"8.

The laws creating the preconditions for improving the position of Roma have been adopted at all levels of $\mathrm{BiH}$. The Law on the Prohibition of Discrimination was adopted in 2009, regulating areas of discrimination, including protection mechanisms and sanctions ${ }^{9}$. The Law on Minorities regulates a set of rights that the $\mathrm{BiH}$ authorities must guarantee to minorities, including the right to language, information, enjoyment of economic and social rights, and participation in the work of government bodies ${ }^{10}$. Following the principles regulated by the BiH Law on Minorities, the entities also adopted laws on minorities, their provisions mostly regulating the rights of the minorities in the same manner. In the RS, adopted the Law on the Protection of the Rights of National Minorities in 2004, and the FBiH Law on the Protection of the Rights of National Minorities was adopted in $2008^{11}$.

The right to education is a right provided within the Universal Declaration of Human Rights and so far guaranteed in most of the constitutions of each country. The International Covenant on Economic, Social, and Cultural Rights (ICESCR) provides inclusive right on education to all citizens within a country and specifically article 13 gurantee this right as a fundamental human right which is a neccesary mean of realizing other human rights. According to it: "Education is the primary means by which economically and socially marginalized people can lift from poverty and provide the means to partecipate fully in their communities which plays a key role in empowering women, preventing child exploitation, promoting human rights and democracy, protecting the environement and controlling population growth. Education is recognized as one of the best financial investments that state can make"12. General Coments No.13

Taking into account the two mentioned aspects of the right to education, more inclusive education for Roma Minority and the right to be taught learn in the minority language, which falls firstly under the domestic provisions which are regulated by law and secondly it falls to be implemented under Art 13 of the ICESCR, this policy paper will analyse the case of roma minority, providing evidence of the current situation and providing different solutions that can be aplicable. Different actors and target groups are implied as policy maker/provider and policy implementation and the beneficiary group are the roma community. The reccomandations will frame possible solution for policy changing and providing further research on the right of education to other minority groups within Bosnia and Herzegovina.

\footnotetext{
${ }^{5}$ Ibid pp. 5

${ }^{6}$ Institution of Human Rights Ombudsman of Bosnia and Herzegovina "Annual Report on results of activities of the Human Rights Ombudsman of Bosnia and Herzegovina" 2013 pp.13

7 Ibid pp.12

8 Stephan Müller, (2011), "National Policies towards Romani Women in the Western Balkans" pp. 15

9 Institution of Human Rights Ombudsman of Bosnia and Herzegovina, 2013 "Special report on the Status of Roma in Bosnia and Herzegovina" pp.16

${ }^{10}$ Constitution of BiH gurantees the right to education to all citizens of the country (constituent people and "others"). Refer to art. 5 and art.12

11 Institution of Human Rights Ombudsman of Bosnia and Herzegovina "Annual Report on results of activities of the Human Rights Ombudsman of Bosnia and Herzegovina" 2013 pp.12

12 General Coments No.13 on 1999 Available at http://www.refworld.org/docid/4538838c22.html
} 


\section{Roma Right to Education - Tracking the Issue}

Bosnia and Herzegovina represents one of the many examples within the South Eastern European countries when the minority group such as Roma group are treated as a second "hand" citizens. Although Roma have been officially recognized as a national minority since Bosnia and Herzegovina's adoption of legislation on minorities in 2003, their political rights are shrinked for representation only to municipal level on separate electoral lists for national minorities ${ }^{13}$. The 2003 Law on the Protection of the Rights of Members of National Minorities, (PRMNM) stands as the first law that regulates the rights and obligations of national minorities and the obligation of government bodies in $\mathrm{BiH}$ to respect, protect, preserve and develop the culture of national minorities. Within the Council of Ministers of BiH, the Board for Romani Issues was established to provide political representation and increasing Roma's socio-economic status through better access to education and employment as well as though improving infrastructure in Romani settlements. After more than a decade of the Board's creation, evidence of its effectiveness in fulfilling its role is still lacking.

A further step was the adoption of the Action Plan on the Education Needs of Roma and Members of Other National Minorities in Bosnia and Herzegovina in 200414, with the aim of improving Roma's access to the system of mainstream education in $\mathrm{BiH}$ by addressing obstacles while emphasizing the participation of Romani communities in contributing to full inclusion in education, the first of the Action Plan's two parts focuses exclusively on Roma, identifying needs, enumerating measures to address the needs and specifying the institutions responsible for implementation.

Another important policy was the adoption in 2005 of the Strategy of BiH for Solving the Problems of the Roma, which enumerates fifteen areas in which concrete actions are necessary to improve the social status of the Roma national minority ${ }^{15}$. In the area of education, the Strategy does not define specific tasks or responsibilities, but calls for implementation of the Action Plan on the Education Needs of Roma and Members of Other National Minorities in BiH. Also $\mathrm{BiH}$ joined the Decade of Roma Inclusion in 2008 serving as a National Action Plan for Roma on Education.

Although, the institutional mechanisms was established during the last years in order to stimulate inclusion for Roma rights and increase the numbers of children in school the Committee for Elimination of all Forms of Racial Discrimination (CEFRD) noted with concern that the National Strategy for Roma reportedly failed to identify specific measures, allocate sufficient funds, or identify competent bodies and recommended that "the State Party review the National Strategy for Roma to ensure that it identifies specific measures, establishes adequate budgetary allocations, and identifies the bodies responsible for its implementation"16.

Another difficulty that was faced regarded the right to education on the own community language. According to the report: "Moreover, the State Party should include, in its next periodic report, detailed information on the measures implemented to give effect to the linguistic and educational rights of Roma protected under the Law on the Protection of Rights of Persons Belonging to National Minorities..."17.

This concerns raised by CEFRD were an object of the study conducted by the UNDP, which concluded that the Roma community faces somehow unequal rights on the right to education, trigger figures of the educational status of Romani adults and the participation of Romani youth at the current stage in the education system are very low. According to this survey, nearly $40 \%$ of the Romani community responded that did not even finish primary education which represents 4 times more than those non-romani people who have not finished elementary school as well ${ }^{18}$. Only a small majority finished secondary education (Romani women: 4.53\%; Romani men: 9.19\%) compared 42.58\% among nonRomani women and $52 \%$ among non-Romani men and not a single person of the Romani sample finished university ${ }^{19}$.

Barriers addressing the needs identified in the Action Plan included insufficient attention in the document to actions needed at the school level, as well as the absence of specifications about timeframes and resources for implementation. Although the finalization of the Action Plan was expected in early 2010, the outcome showed a need to rivitalise rather to

\footnotetext{
13 The Roma community political right and political representation is partly because no romani candidate can run for MP's or presidential candidancy. For further reading see: Centralna izborna komisija, Izborni zakon Bosne i Hercegovine (neslužbeni prečišćeni tekst) [Electoral Law of Bosnia and Herzegovina], available at http://www.izbori.ba/ documents/ZAKONI/POIZpw110508.pdf.

14 Institution of Human Rights Ombudsman of Bosnia and Herzegovina, 2013 "Special report on the Status of Roma in Bosnia and Herzegovina" pp.16

${ }^{15}$ Ibid pp.34

${ }_{16}$ Ibid pp.39

17 Ibid pp.38

18 UNDP Survey, 2006, "At Risk - The Social Vulnerability of Roma, Refugees and Displaced Persons in Southeast Europe"

19 Sarajevo Open Center "Annual Report on the State of Women's Rights in Bosnia and Herzegovina in 2013" 
conclude the end of that policy. Thus on the same year a new Action Plan was conceived with no finalization date projected, tackling again the failure of the implementation of the policy mechanism in the country.

\subsection{Analysing the issue}

From the standpoint of quality education for Roma, the most significant weaknesses of the current system of education in Bosnia and Herzegovina relate to the following areas:

- The absence of an adequate database on the Romani population in general and the lack of systematic collection of data on Romani pupils in particular as a basis for the design and monitoring of appropriate measures to target the most significant barriers to Roma's education.

- The extreme complexity of the governance structure for education in BiH which makes it difficult to monitor system performance in general and the inclusion of Roma in particular.

- The extremely low rates of coverage of Roma at all levels of education.

- The continued overrepresentation of Roma in special education.

- Insufficient measures to address language barriers faced by Romanes-speaking Roma.

The rights to Roma minority to have a proper education and taught in their language is often neglected in the areas where one of the constituent people of $\mathrm{BiH}$ represents the majority of the population, Roma children are obliged to be taught in the language of the majority only. According to the European Commission Report on BiH (2004) defined social inclusion as the process that provides people exposed to the risk of poverty and social exclusion with the opportunity and means for full participation in economic, social and cultural life of the society in which they live ${ }^{20}$.

As such, from the state prespective, the Ministry of Human Rights and Refugee which deals as a primary state actor with the issue related of Roma minority (MHRR) presented a report on Implementation of the Decade of Roma Inclusion in BiH dated 20 August 2013 which stated that, "...the key barriers that limit the opportunities and access to high-quality education of Roma are extreme poverty, changes in the place of residence, lack of understanding of the importance of education for their children, and others, as well as lack of financial means at the state level..." to implement all the measures foreseen in the Action Plan for education of Roma. Namely, no financial means were appropriated at state level in 2012 and 2013 in support of the implementation of any measure from the Revised Action Plan of BiH on the educational needs of Roma. However, competent ministries of education do allocate budgetary funds, but they are still not sufficient to support enrolment, attendance and graduation from school for all Roma children ${ }^{21}$.

This view emphasize the problem in budgetary allocation to support state initiatives for more inclusion of Roma rights on education, although there has been international support, such as IPA funds to support state-led initiatives. As the European Commission Anex Report of IPA Funds in 2014 states as follow: "IPA funds has supported the country with this budgetary allocation...; ... and in the following year IPA II will support Bosnia and Herzegovina in the implementation of its Roma action strategy and related action plans in the fields of education, employment, housing and healthcare"22

As a result of the Revised Action Plan, issued in 2010 after the fail of the previous one, the same report states that although the difficulties there has been an increased enrolment of Roma children in primary, secondary, as well as higher education. Also there are a much smaller number of children leaving primary and secondary education ${ }^{23}$. Such statements are not provided with data evidence which make them unrealistic an somehow a propaganda to camouflage the fail of state institution for achieving such goals.

Having analysed the issue from a state institution prespective, such as MHRR and the Revised Action Plan we need a second evidence to support our argumentation regarding the lack of state implementation mechanism for more inclusive Roma minority rights on education. In such actors of the civic sector play a crucial role in the implementation phases. A total number of Romani nongovernmental organisations round 50, but only 38 are active, dividing this number between Repubika Srpska (8) and (30) in the FBiH. ${ }^{24}$

\footnotetext{
20 European Commission 2014 "Annex 1 Instrument For Pre-Accession Assistance (IPA II)" pp.6

${ }^{21}$ Institution of Human Rights Ombudsman of Bosnia and Herzegovina, 2013 "Special report on the Status of Roma in Bosnia and Herzegovina" pp.39

22 European Commission 2014 "Annex 1 Instrument For Pre-Accession Assistance (IPA II)" pp.23

${ }^{23}$ Institution of Human Rights Ombudsman of Bosnia and Herzegovina "Annual Report on results of activities of the Human Rights Ombudsman of Bosnia and Herzegovina" 2013 pp.106

24 Advancing Education of Roma in Bosnia and Herzegovina (2009), "Country Assessment and the Roma Education Fund's Strategic Directions" pp.23
} 
From survey conducted and research on Roma inclusion rights in education from UNDP and other actors in the field there has been shown this outcomes which are presented in table ${ }^{25}$. Although there is a positive shift to more enrolled children in pre-school system and primary education, on the secondary the difference is approximitely unchanged, taking account nearly 10 years of difference. Thus with the same position in terms of education, Roma associations emphasize a somewhat positive shift in terms of enrolment of Roma children in the first grade of primary school and provision of textbooks, but the small number enrolled in secondary school and university students is worrisome. As root causes of low level of education among Roma (on average), the associations highlights the poor implementation of the Revised Action Plan of 2010 and its outcome in future. This perspective represent the second evidence of the problems that are related with the lack of Roma rights for more inclusive schooling and right of education. Almost all the actors provides concern only to increase the number of enrolled students, leaving behind of the issue the right to educate in the Romani language. Insofar in the following section I will discuss possible strategies policy options to change and new ones to be presented as alternatives.

\section{Strategies for Policy Options}

The previous discussion related firstly explaining the issue (actors, policies, implementation, laws), secondly analyzing the problem from (state institutions prespective and civil society prespective) and now I will discuss strategies that can be presented as options for policy change. The provision of basic education rights can be assumed as coumnity right but also as an individual right, implying the principle of universal and free basic education for every child, and the granting of special, group rights to students of different cultural groups. Multicultural education emphasises the need to preserve the specific cultures of minority groups, for example through linguistically and culturally sensitive curricula.

A number of options exist for policy makers: a single language as the main medium of public education, a single language of instruction with transitional bilingualism, or a concerted effort to use both majority and minority languages for instruction. These options can be offered on the basis of universality or territoriality, the promotion of individual vs. collective rights, tolerance or promotion, and 'norm-and-accommodation' or recognition principles.

Special schooling - The common practice of streaming Roma children into "special" schools or classes results in Roma overrepresentation in schooling that is ostensibly for children with (mental) disabilities or other special needs. This special schooling constitutes per se segregated education-irrespective of the ethnic composition of the student bodybecause activities in these facilities are separated and different from those associated with regular education. They also reduced curricula and rarely enable their students to enter the regular school system or the labour market.

Universal access to early childhood education - Many studies underscore the important links between early childhood education and future educational progress. Not surprisingly, low pre-school attendance rates disadvantages Roma students over the long term. No further research is needed to make that case: what is needed now is the removal of barriers to early childhood education. These concern physical access (insuficient numbers of kindergartens, remoteness from Roma dwellings), income poverty (the inability to meet basic needs and cover out-of-pocket costs associated with school attendance), and prejudice-non-Roma parents' unwillingness to have their children attend kindergarten with Roma kids. Holistic efforts to address these barriers are needed as long-term investments in decreasing Roma exclusion and vulnerability. At the same time, steps need to be taken to ensure that pre-schools do not facilitate or reinforce ethnic streaming.

Encouraging greater Roma participation in primary, lower secondary and post-compulsory education - In order to reduce the numbers of early school leavers and increase Roma participation in secondary and tertiary education, governments need to identify the points in the education system at which early leavers are most likely to drop out.Attention need to be payed to initial school enrolment. There is a need of educational monitoring systems which would detect school absences, and if necessary enforce attendance. Regular primary schools must be obliged to enrol pupils living in the relevant jurisdictions; toleration of non-enrolment should be sanctioned. If not already established, the right to education for every child with or without proper documents (e.g., resident permits, identity cards) needs to be enforced by law. Also create mechanisms to keep students in school after compulsory schooling ends.

Transitions from compulsory to post-compulsory schooling are crucial - Ensuring that all Roma complete compulsory schooling, and supporting their transition to post-compulsory education, should be major priorities in Roma education interventions. Efforts to lower the costs of education, investment in school quality (especially in poor regions),

${ }^{25}$ Table 1 is found at Anex, pp. 13 Brüggemann, C. (2012). Roma education in comparative perspective", pp.5 
and the introduction of financial incentives to subsidize participation in post-compulsory education, should be supported. Out-of-pocket school costs (for travel, extracurricular activities, school materials, meals) are high for poor families. The introduction of attendance subsidies (e.g., conditional cash transfers-higher child allowances combined with the monitoring of school attendance) could lead to better postcompulsory educational attainment rates. Close cooperation between educational institutions at both ends of the transition from compulsory to non-compulsory education, and professional guidance for students who are struggling to enter post-compulsory education, might increase attainment rates.

\section{Conclusions}

After discussing the four options that would increase inclusiveness for Roma right to education, I find that "Encouraging greater Roma participation in primary, lower secondary and post-compulsory education" is the most reliable option that would imply state institutional mechanisms to be changed and a different approach to tackle regarding Roma community.

Insofar, firstly there is a need to change the approach toward Roma community. We should not limit the enrolement in school by registered citizens, residence certificate, medical care insurance and other specifities required in order for submission in public schools. We have to except this enrolement that are voluntary and during the education process we might achieve needed registration not only for the child but for the entire family. Secondly the need for a yearly stable fund for the Roma Education Support. This fund should be allocated to the education system within the country and than to be distributed among state entities (cantonal level, Brcko district and Republika Srpska). This fund should not be allocated equally but to the concentration of Roma minorities from the data that are provided form different organizations and the census of 1991. Thirdly there is a need to change the system of schooling which is based on segregation policy. Keeping Roma pupils in separate schools in order to achieve higher education creates exclusion from the educational system and less opportunity for integration in the society. Also Roma pupils should not be concentrated in one school that is close to the area were they live but the pupils should have the opportunity to choose all the schools of a certin area, a city or communal area. Also the education ublic institution that is in charge for that administrative area such as cantonal level should provide means of transportation and additional supplements to support relocation of roma pupils in other school although they might be far from their area of residence. This would promote multiculturalism and better integration of the Roma children on their right to education.

A fourth need to be implied rather to be changed relates the right to have education in the language of the minority group. This right is fully denied from the educational system which is divided among the three constituent people ethnic languages on their territories were they constitute majority but the main arguments that support this lack stands to the funds that would create such classes, teaching stuff and university programs of Romani language, culture and history. In fact the change should start with the opening of studies on minorities of $\mathrm{BiH}$ in the universities, taking western European experience such as Finland project of $2014^{26}$. Than after having the first graduates of Romani language and history, this new education specialists would have the ability to teach in this specific classes, attented from Roma pupils but also as optional courses for other non Roma and what is more important giving opportunity that this classes would be on the studying curriculums and graded as the other optional classes.

This four achievements should be presented as short-term policies. On the other hand the long terms should imply legislative change, such as the preamble of the constitution of $\mathrm{BiH}$ which should not state of the constituent people but to the citizens of $\mathrm{BiH}$. This would create the ability that he right to education should be guaranteed to all ethnic groups within the country, no matter they are national minorities and the right to education in the minority language can be applied.

The last achievement would be rather un-realistic for the righting of this policy paper that have short to medium terms perspectives the ability to imply such changes would not even need to such policy strategies presented above. Although the policy solution that I analysed and argued in favour would be presented in the following concentrated reccomandations.

${ }^{26}$ Romani Language and Culture at the University of Helsinki 2014-2015 pp.1 https://tuhat.halvi.he/sinki.fi/portal/files/42015274/ brochures_subject_A4_FINAL_US.pdf 


\section{Recommendations}

- Supporting enrolement of Roma children in any manner - this would imply creating more facilitative process of enrolement of a pupils to a certain school, by first registering and than starting to require the residence documents and citizen registration. If the family of the child would be not registered as citizen of BiH than this should be a priority to register the entire family and cover all financial fees that are implied on this process and on the education of their child/children in the school enrolled

- Creation of special classes within the school rather special school - In order to achieve compatibility with the school program of a certain academic year, a pupil or student should get special classes with accelerated program in order to reach a certain level of the education program. This should be applied at least to the compulsory schooling, in order to achieve much Roma pupils that finish the primary education. This classes would be grounded on the same multicultural school rather on special schools which segregate Roma from the others.

- Budgetary Fund for Roma Education - this fund should be spread among the administrative division of the entities level and Brcko district with the principle of the most Roma concentration within that certain area. This would imply better financial support for the school programs and at the same time rise the number of new citizen that would registered in order to achieve this support for the education of their children.

- Romani classes goal - Expressed as a goal because it implies a three-step mechanism to achieve the primar goal. Firstly the creation of university studies curricula and opening of the undergraduate programs. Secondly creating curricula in primary and secondary school programs as optional classes. Employing this graduated students as teachers/specialists of Romani language and history for this classes. Thirdly Grading the class as the other optional classes, making somehow compulsory in schools that have at least one Roma students and opening it to other non roma pupils.

\section{References}

Action Plan of Bosnia and Herzegovina for Addressing Roma Issues in the Fields of Employment, Housing and Health Care (2008) Available at: http://www.romadecade.org/cms/upload/file/9296_file2_action-plan-on-employment-housing-and-health-care-introduction.pdf

Advancing Education of Roma in Bosnia and Herzegovina 2009 Country Assessment and the Roma Education Fund's Strategic Directions Avaiable at: http://www.romaeducationfund.hu/sites/default/files/publications/ca_bosnia_english_2010.pdf

Brüggemann, C. (2012). Roma education in comparative perspective. Analysis of the UNDP/World Bank/EC regional Roma Survey. Roma Inclusion Working Papers. Bratislava: UNDP Regional Bureau for Europe and the CIS. Avaiable at: http://www.eurasia.undp.org/content/dam/rbec/docs/Roma-education-in-comparative-perspective.pdf

Centralna izborna komisija, Izborni zakon Bosne i Hercegovine (neslužbeni prečišćeni tekst) [Electoral Law of Bosnia and Herzegovina], Available at: http://www.izbori.ba/ documents/ZAKONI/POIZpw110508.pdf.

European Commission "Annex 1 Instrument For Pre-Accession Assistance (Ipa li) Indicative Strategy Paper For Bosnia And Herzegovina (2014-2017) Adopted On 15/12/2014 Avaiable at: http://ec.europa.eu/enlargement/pdf/news lannexe_acte_autonome_nlw_part1v1.pdf

International Covenant on Economic, Social, and Cultural Rights (ICESCR), the General Coments No. 13 Avaiable at: http://www.refworld.org/docid/4538838c22.html

Institution of Human Rights Ombudsman of Bosnia and Herzegovina "Annual Report on results of activities of the Human Rights Ombudsman of Bosnia and Herzegovina" Sarajevo 2013 Avaiable at: http://www.ombudsmen.gov.ba/documents lobmudsmen_doc2014042313584567eng.pdf

Institution of Human Rights Ombudsman of Bosnia and Herzegovina, "Special report on the Status of Roma in Bosnia and Herzegovina" Sarajevo 2014 Avaiable at: https://www.osce.org/bih/110495?download=true

Romani Language and Culture at the University of Helsinki 2014-2015 Avaiable at: https://tuhat.halvi.helsinki.fi/portal/files 142015274/brochures_subject_A4_FINAL_US.pdf

Stephan Müller, (2011) "National Policies towards Romani Women in the Western Balkans" September 2011 Country Paper on Bosnia and Herzegovina CARE Northwest Balkans http://www.romadecade.org/cms/upload/file/9376_file2_country-paper-on-bosniaand-herzegovina--national-policies-towards-romani-women-in-the-western-balkans.pdf /

Sarajevo Open Center "Annual Report on the State of Women's Rights in Bosnia and Herzegovina in 2013" Esther Garcia Fransioli Human Rights $\quad$ Paper 20 Avaiable http://www.diskriminacija.ba/sites/defaultffiles/Annual\%20Report\%20on\%20Women\%20Rights,\%202013.pdf

UNDP Survey, 2006, "At Risk - The Social Vulnerability of Roma, Refugees and Displaced Persons in Southeast Europe, Bratislava,; data sets Available at: http://vulnerability.undp.sk 
Anex

Table 1

\begin{tabular}{|l|c|c|c|}
\hline & $\begin{array}{c}2004 \text { Roma } \\
\text { Minority }\end{array}$ & $\begin{array}{c}2011 \text { Roma } \\
\text { Minority }\end{array}$ & $\begin{array}{c}2011 \text { Non } \\
\text { Roma 2011 }\end{array}$ \\
\hline Attendance for Roma kindergarten 3-6 years & $4 \%$ & $6 \%$ & $13 \%$ \\
\hline Attendance for Roma in primary school 7-13 years & $36 \%$ & $45 \%$ & $95 \%$ \\
\hline Attendance for Roma at least lower secondary education 17-23 years & $5 \%$ & $6.5 \%$ & No data \\
\hline
\end{tabular}

